\title{
PENGARUH KUALITAS PELAYANAN APOTIK YANG TERDIRI DARI TANGIBLES, RELIABILITY, RESPONSIVENESS, ASSURANCE, EMPATHY TERHADAP KEPUASAN PASIEN PADA RSUD PANGERAN JAYA SUMITRA KOTABARU - KALIMANTAN SELATAN
}

\author{
Wahyu Rofian Noor \\ Sekolah Tinggi Ilmu Ekonomi Pancasetia Banjarmasin \\ Jl. Ahmad Yani Km. 5.5 Banjarmasin \\ wahyurnkalsel@gmail.com
}

\begin{abstract}
Quality greatly affects patient satisfaction, where the patient will feel satisfied if the patient's perception of the quality of service is as expected by the patient. And will feel dissatisfied if the quality of service is not as expected. With the results of minimal service quality, of course, patient satisfaction is also not optimal.
\end{abstract}

Therefore, this study aims to determine the effect of physical evidence (tangible), reliability (reliability), responsiveness (responsiveness), attention (empathy), and assurance (assurance) on patient satisfaction. The population in this study were all patients at the Jaya Sumitra Hospital, Kotabaru, South Kalimantan, totaling 94 people. The researcher used the Slovin sampling technique. Analysis of the data in this study using a multiple regression models.

The results of this study indicate that physical evidence (tangible), reliability (reliability), responsiveness (responsiveness), attention (empathy), and assurance (assurance) to patient satisfaction.

Keywords: Physical Evidence (Tangible), Reliability (Reliability), Responsiveness (Responsiveness), Attention (Empathy), Assurance (Assurance) and Patient Satisfaction

ABSTRAK : Kualitas sangat mempengaruhi kepuasan pasien, yang mana pasien akan merasa puas jika persepsi pasien terhadap kualitas pelayanan sesuai yang diharapkan pasien. Dan akan merasa tidak puas jika kualitas pelayanannya tidak sesuai yang diharapkan. Dengan hasil kualitas pelayanan yang minim tentunya kepuasan pasien juga tidak maksimal.

Oleh karena itu, penelitian ini bertujuan untuk mengetahui pengaruh Bukti fisik (tangible), keandalan (reliability), daya tanggap (responsiveness), perhatian (empathy), dan jaminan (assurance) terhadap kepuasan pasien. Populasi dalam penelitian ini adalah seluruh pasien di RSUD Jaya Sumitra Kotabaru Kalimantan Selatan yang berjumlah 94 orang. Peneliti menggunakan teknik pengambilan sampel Slovin. Anailisis data dalam penelitian ini menggunakan model regresi berganda.

Hasil penelitian ini menunjukkan bahwa Bukti fisik (tangible), keandalan (reliability), daya tanggap (responsiveness), perhatian (empathy), dan jaminan (assurance)berpengaruh terhadap kepuasan pasien.

Kata kunci: Bukti Fisik (Tangible), Keandalan (Reliability), Daya Tanggap (Responsiveness), Perhatian (Empathy), Jaminan (Assurance) Dan Kepuasan Pasien 


\section{LATAR BELAKANG}

Kepuasan pasien dalam menilai mutu atau pelayanan yang baik, dan merupakan pengukuran penting yang mendasar bagi mutu pelayanan. Hal ini tentu akan memberikan informasi terhadap suksesnya pemberi pelayanan bermutu dengan nilai dan harapan pasien yang mempunyai wewenang sendiri untuk menetapkan standar mutu pelayanan yang dikehendaki. Kepuasan pasien adalah perasaan senang atau kecewa seseorang yang muncul setelah membandingkan antara kinerja (hasil) yang dipikirkan terhadap kinerja (hasil) yang diharapkan.

Angka kunjungan pasien rawat jalan RSUD Pangeran Jaya Sumitra Kotabaru Kalimantan Selatan tahun 2017 sebanyak 8.747 pasien, tahun 2018 sebanyak 9.606 pasien dan tahun 2019 sebanyak 12.596 pasien. Dengan angka kunjungan yang meningkat pada setiap tahunnya, angka kepuasan pasien terhadap pelayanan yang di terima oleh pasien belum maksimal dan berdasarkan tentang alur pelayanan rawat jalan rumah sakit, Instalasi Farmasi ( Apotik ) merupakan tempat terakhir dalam pelayanan kesehatan. Oleh karena itu, alur pelayanan penting untuk mengetahui mutu pelayanan yang ada di rumah sakit untuk tolak ukur rangkaian pelayanan mutu yang diberikan terhadap pasien sehingga dapat menjadi evaluasi kinerja mutu pelayanan

Pelayanan bermutu berarti memberikan pelayanan kepada pasien yang didasarkan pada Standart Kualitas untuk memenuhi kebutuhan dan keinginan mereka, sehingga dapat memperoleh kepuasan yang akhirnya dapat meningkatkan kepercayaan pasien dan akan loyal terhadap rumah sakit untuk meningkatkan kualitas jasa kesehatan, kualitas pelayanan dan kepuasan pasien menjadi indikator keberhasilan penyelenggaraan pelayanan di rumah sakit Karena kualitas pelayanan sangat penting sebagai upaya pemenuhan kebutuhan dan keinginan pasien serta ketetapan penyampaiannya untuk mengimbangi harapan pasien dan dengan kualitas pelayanan yang baik pasien akan merasa puas (pelayanan sesuai dengan yang diharapkan), (Simamora, 2003:180). Namun pada dasarnya kualitas pelayanan yang baik tidak cukup hanya dicapai, tetapi juga dipelihara dan dipertahankan mengingat adanya pergeseran kebutuhan, harapan, dan keinginan pasien dan berbagai pihak yang berkepentingan. Untuk itu, rumah sakit sebagai industri jasa kesehatan diharapkan dapat memberikan pelayanan yang lebih berkualitas dan konsisten. Kuncinya adalah memenuhi atau melebihi harapan kualitas pelayanan pasien, sehingga dapat menciptakan loyalitas pasien.

Berdasarkan hasil pemaparan diatas maka peneliti merasa tertarik untuk melakukan penelitian dengan judul "Pengaruh Kualitas Pelayanan Apotik Yang Terdiri Dari Tangibles, Reliability, Responsiveness, Assurance, Empathy Terhadap Kepuasan Pasien Pada RSUD Panageran Jaya Sumitra Kotabaru Kalimantan Selatan"

Berdasarkan paparan latar belakang dan masalah yang dirumuskan diatas maka penelitian ini bertujuan :

1. Untuk menganalisis dan membuktikan Bukti Fisik (Tangibles), Reliabilitas (Reliability), Ketanggapan (Responsiveness), Jaminan (Assurance), dan Empati (Empathy) berpengaruh secara simultan terhadap Kepuasan Pasien Pada RSUD Pangeran Jaya Sumitra Kotabaru Kalimantan Selatan.

2. Untuk menganalisis dan membuktikan Bukti Fisik (Tangibles), Reliabilitas (Reliability), Ketanggapan (Responsiveness), Jaminan (Assurance), dan Empati (Empathy) berpengaruh secara parsial terhadap Kepuasan Pasien Pada RSUD Pangeran Jaya Sumitra Kotabaru Kalimantan Selatan

3.

Untuk mengetahui varibel yang Dominan berpengaruh 
Bukti Fisik (Tangibles), Reliabilitas (Reliability), Ketanggapan (Responsiveness), Jaminan (Assurance), dan Empati (Empathy) terhadap Kepuasan Pasien Pada RSUD Pangeran Jaya Sumitra Kotabaru Kalimantan Selatan.

\section{STUDI LITERATUR}

Kualitas adalah kepuasan pasien sepenuhnya (full costumer satisfaction). Suatu produk, baik barang ataupun jasa dapat dikatan berkualitas apabila dapat memeberi kepuasan secara penuh kepada masyarakat atau pasien, yaitu sesuai dengan apa yang diharapkan pasien. Feigenbaum, (1991:7).

Kualitas merupakan suatu hal yang menentukan akan keberhasilan suatu pelayanan yang dilaksanakan baik itu berupa barang atau jasa, yang sesuai dengan apa yang diharapakan oleh masyarakat. Triguno dalam bukunya yang berjudul budaya kerja, menciptakan lingkungan yang kondusif untuk meningkatkan produktivitas kerja sebagai berikut: "standar yang harus dicapai oleh seseorang atau kelompok atau lembaga organisasi mengenai kualitas sumber daya manusia, kualitas cara kerja, proses dan hasil kerja atau produk yang berupa barang dan jasa. Berkualitas mempunyai arti memuaskan kepada yang dilayani, baik internal maupun eksternal dalam arti optimal pemenuhan atas tuntutan masyarakat" Triguno, (1997:76)

Berdasarkan pendapat di atas, kualitas sebagai standar yang harus dicapai oleh seseorang, kelompok, atau lembaga organisasi mengenai kualitas SDM, kualitas cara kerja, serta barang dan jasa yang dihasilkan. Kualitas juga mempunyai arti yaitu memuaskan kepada yang dilayani baik secara internal maupun eksternal yaitu dengan memenuhi kebutuhan dan tuntutan pasien atau masyarakat

Pelayanan publik merupakan pemberian cara dari suatu organisasi untuk memberikan layanan atau melayani keperluan orang atau masyarakat dan/atau organisasi lain yang mempunyai kepentingan pada organisasi tersebut, sesuai dengan aturan pokok dan tata cara yang ditentukan dan ditujukan untuk memberikan kepuasan kepada penerima pelayanan. Mengenai peran dan fungsi pemerintahan dalam pelayanan Arief Budiman menjelaskan: "Sebagaimana fungsi pemerintah dalam melakukan pelayanan yang berkaitan dengan kepentingan umum. Negara yang dijalankan melalui pemerintahannya mempunyai misi tersendiri yaitu menciptakan masyarakat yang lebih baik dari sekarang" Budiman, (1996:2).

Kualitas pelayanan sebagai standar yang harus dicapai oleh seseorang, kelompok, atau lembaga organisasi mengenai kualitas SDM, kualitas cara kerja, serta barang dan jasa yang dihasilkan. Kualitas juga mempunyai arti yaitu memuaskan kepada yang dilayani baik secara internal maupun eksternal yaitu dengan memenuhi kebutuhan dan tuntutan pasien atau masyarakat.

Berdasarkan penelitian yang dikembangkan oleh Parasuraman, Zeitham dan Berry (1998), Pasien mengevaluasi lima dimensi kualitas pelayanan yaitu :

1. Tangibles (berwujud) : meliputi fasilitas fisik penyedia service, peralatannya serta penampilan petugas.

2. Reliability (kehandalan) meliputi kemampuan perusahaan jasa untuk memberikan pelayanan yang dijanjikan secara akurat dan terpercaya.

3. Responsiveness (ketanggapan) : meliputi kesediaan petugas perusahaan untuk membantu pasien dan memberikan kepada mereka pelayanan yang cepat.

4. Assurance (jaminan) : meliputi pengetahuan dan keramahan petugas perusahaan dan kemampuan mereka menjamin kinerja yang baik sehingga menimbulkan kepercayaan dan 
keyakinan pasien.

5. Empathy (empati) : meliputi perhatian yang bersifat individual kepada pasien dan berupaya memahami keinginan pasien

\section{KERANGKA KOPSEPTUAL DAN HIPOTESIS}

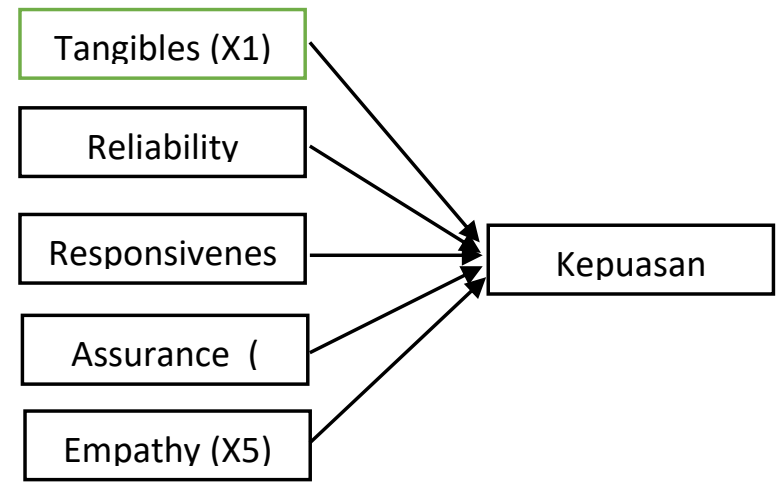

Berdasarkan Rumusan masalah dan kerangka konseptual penelitian diatas maka hipotesis penelitian ini disampaikan sebagai berikut :

1. Tangibles , Reliability, Responsiveness ,Assurance dan Emphaty Berpengaruh signifikan secara simultan terhadap Kepuasan Pasien layanan Apotik Pada RSUD Jaya Sumitra Kotabaru Kalimantan Selatan

2. Tangibles , Reliability, Responsiveness ,Assurance dan Emphaty Berpengaruh signifikan secara Parsial terhadap Kepuasan Pasien Layanan Apotik Pada RSUD Jaya Sumitra Kotabaru Kalimantan Selatan

3. Emphaty, Berpengaruh Dominan terhadap Kepuasan Pasien layanan Apotik Pada RSUD Jaya Sumitra Kotabaru Kalimantan Selatan.

\section{METODE PENELITIAN}

Jenis dan Sumber Data

Berikut ini terdapat beberapa jenis-jenis data, terdiri atas:

- Data kuantitatif adalah data yang dapat diinput kedalam skala pengukuran statistik. Fakta dan fenomena dalam data ini tidak dinyatakan dalam bahasa alami, melainkan dalam numerik.

- Data kualitatif adalah data yang dapat mencakup hampir semua data non-numerik. Data ini dapat menggunakan kata-kata untuk menggambarkan fakta dan fenomena yang diamati.

Sumber-sumber data :

- Data primer adalah data yang dikumpulkan oleh peneliti sendiri atau dirinya sendiri. Ini adalah data yang belum pernah dikumpulkan sebelumnya, baik dengan cara tertentu atau pada periode waktu tertentu.

- Data Sekunder adalah data yang dikumpulkan oleh orang lain, bukan peneliti itu sendiri. Data ini biasanya berasal dari penelitian lain Populasi dan Sampel

Populasi Menurut Sugiarto (2017: 136), Populasi adalah sekumpulan individu yang memiliki karakteristik khas yang menjadi perhatian dalam suatu penelitian (pengamatan) pada ruang lingkup yang ingin diteliti. Populasi dalam penelitian ini yaitu berjumlah 1450 orang.

Menurut Sugiarto (2017: 137), Sampel adalah sebagian dari anggota populasi yang diambil menurut prosedur tertentu sehingga diharapkan dapat mewakili populasinya. Dalam penelitian ini, semua populasi akan dijadikan sampel yaitu berjumlah 94 orang.

Teknik Pengumpulan data sebagai berikut:

1. Wawancara merupakan teknik pengumpulan data yang dilakukan melalui tatap muka dan tanya jawab langsung antara peneliti dengan narasumber. Dalam hal ini data yang diperoleh dengan melakukan wawancara dengan beberapa pasien layanan apotik RSUD Jaya Sumitra Kotabaru Kalimantan Selatan.

2. Angket (questionnaire) merupakan teknik pengumpulan data yang dilakukan dengan cara memberikan 
seperangkat pertanyaan atau pernyataan kepada responden untuk dijawab.

Teknik Analisis data yang diperoleh dari hasil pengisian kuesioner akan dianalisis menggunakan rumus yang sesuai dengan pendekatan penelitian. Peneliti melakukan pengujian analisis data menggunakan SPSS versi 25.0.

Lokasi Penelitian ini dilakukan pada : Penelitian ini dilakukan pada : RSUD Pangeran Jaya Sumitra Jl. Brigjend H. Hasan Basri No.39, Semayap, Pulau Laut Utara, Kab. Kotabaru, Kalimantan Selatan 72112Jdwal Penelitian ini dilakukan pada bulan April - Agustus 2021

\section{HASIL PENELITIAN \\ PEMBAHASAN}

DAN

Analisis Hasil Penelitian

Uji Validitas

\begin{tabular}{|c|c|c|c|c|}
\hline No. & Variabel & $\begin{array}{c}\mathrm{R} \\
\text { hitung }\end{array}$ & $\begin{array}{c}\mathrm{R} \\
\text { tabel }\end{array}$ & Status \\
\hline \multirow{5}{*}{1.} & \multirow{5}{*}{ Tangibel (X1) } & 0,689 & \multirow{5}{*}{0,168} & \multirow{5}{*}{ Valid } \\
\hline & & 0,749 & & \\
\hline & & 0,710 & & \\
\hline & & 0,743 & & \\
\hline & & 0,591 & & \\
\hline \multirow{5}{*}{2.} & \multirow{5}{*}{ Reliability (X2) } & 0,823 & \multirow{5}{*}{0,168} & \multirow{5}{*}{ Valid } \\
\hline & & 0,717 & & \\
\hline & & 0,745 & & \\
\hline & & 0,619 & & \\
\hline & & 0,616 & & \\
\hline \multirow{5}{*}{3.} & \multirow{5}{*}{$\begin{array}{l}\text { Responsiveness } \\
\text { (X3) }\end{array}$} & 0,327 & \multirow{5}{*}{0,168} & \multirow{5}{*}{ Valid } \\
\hline & & 0,867 & & \\
\hline & & 0,806 & & \\
\hline & & 0,560 & & \\
\hline & & 0,753 & & \\
\hline \multirow{5}{*}{4.} & \multirow{5}{*}{ Assurance (X4) } & 0,575 & \multirow{5}{*}{0,168} & \multirow{5}{*}{ Valid } \\
\hline & & 0,799 & & \\
\hline & & 0,7112 & & \\
\hline & & 0,765 & & \\
\hline & & 0,579 & & \\
\hline \multirow{5}{*}{5.} & \multirow{5}{*}{ Empathy (X5) } & 0,710 & \multirow{5}{*}{0,168} & \multirow{5}{*}{ Valid } \\
\hline & & 0,598 & & \\
\hline & & 0,755 & & \\
\hline & & 0,904 & & \\
\hline & & 0,712 & & \\
\hline \multirow{5}{*}{6.} & \multirow{5}{*}{$\begin{array}{c}\text { Kepuasan Pasien } \\
\text { (Y) }\end{array}$} & 0,714 & \multirow{5}{*}{0,168} & \multirow{5}{*}{ Valid } \\
\hline & & 0,775 & & \\
\hline & & 0,898 & & \\
\hline & & 0,733 & & \\
\hline & & 0,898 & & \\
\hline
\end{tabular}

Sumber : Data diolah SPSS 25.0
Berdasarkan table hasil pengolahan data diatas semua variabel yaitu lingkungan kerja (X1), kompensasi (X2), motivasi (Z), dan kinerja pegawai (Y), menunjukan bahwa seluruh pearson correlation memiliki nilai lebih besar dari $r$ table, artinya seluruh pernyataan tersebut bersifat valid. Seluruh pernyataan tersebut dapat dijadikan alat ukur yang valid dalam analisis berikutnya.

Uji Reliabilitas

\begin{tabular}{|l|l|l|l|}
\hline Variabel & $\begin{array}{l}\text { Cronbach's } \\
\text { Alpha }\end{array}$ & Kriteria & Kesimpulan \\
\hline Tangibel & .727 & 0,6 & Reliabel \\
\hline Reliability & .748 & 0,6 & Reliabel \\
\hline Responsiveness & .661 & 0,6 & Reliabel \\
\hline Empathy & .722 & 0,6 & Reliabel \\
\hline Assurance & .794 & 0,6 & Reliabel \\
\hline $\begin{array}{l}\text { Kepuasan } \\
\text { Pasien }\end{array}$ & .864 & 0,6 & Reliabel \\
\hline
\end{tabular}

Sumber : Data diolah SPSS 25.0

Dari table diatas dapat diketahui bahwa seluruh variabel memiliki Cronbach's Alpha $>0,60$. Dengan demikian variabel Tangibel (X1), Reliability (X2), Responsiveness (X3), Assurance (X4), Empathy (X5), dan Kepuasan Pasien (Y) dapat dikatakan reliabel dan instrument yang diajukkan dalam penelitian ini layak dijadikan alat pengumpulan data

\section{Uji Asumsi Klasik}

\section{Model Sub Struktural 1}

\section{Uji Normalitas dengan Grafik P-Plot}

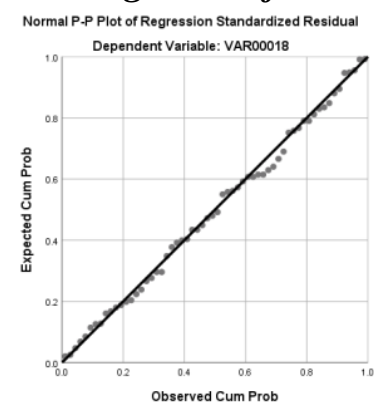

(Gambar 5.1. Grafik P-Plot)

Berdasarkan gambar di atas, diketahui bahwa data menyebar disekitar garis diagonal dan mengikuti arah garis diagonal 
atau grafik histogramnya menunjukkan pola distribusi normal, maka model regresi memenuhi asumsi normalitas.

\section{Uji Heteroskedastisitas}

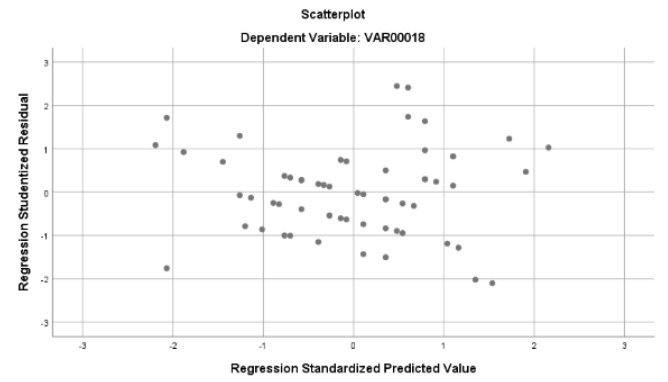

(Gambar 5.2. Hasil Analisis Heteroskedastisitas)

Dari grafik scatterplot pada gambar $4.5 \mathrm{di}$ atas, terlihat bahwa tidak ada pola yang jelas, serta titik - titik menyebar secara acak di atas maupun di bawah angka 0 pada sumbu Y. Hal ini dapat disimpulkan bahwa tidak terjadi heteroskedasitas pada model regresi dalam penelitian ini.

\section{Uji Multikolinearitas}

Tabel 5.10 Uji Multikolinearitas Mode Coefficients $^{\mathrm{a}}$

\begin{tabular}{|c|c|c|c|c|c|c|c|}
\hline \multirow[b]{2}{*}{ Model } & \multicolumn{2}{|c|}{$\begin{array}{l}\text { Unstandar } \\
\text { dized } \\
\text { Coefficien }\end{array}$} & \multirow{2}{*}{$\begin{array}{l}\text { Standard } \\
\text { ized } \\
\text { Coeffici } \\
\text { ents } \\
\text { Beta }\end{array}$} & \multirow[t]{2}{*}{$\mathrm{t}$} & \multirow[t]{2}{*}{$\mathrm{Si}$} & \multicolumn{2}{|c|}{$\begin{array}{l}\text { Collinearit } \\
\text { y Statistics }\end{array}$} \\
\hline & $\mathrm{B}$ & $\begin{array}{l}\text { Std. } \\
\text { Erro } \\
\mathrm{r} \\
\end{array}$ & & & & $\begin{array}{l}\text { Tolera } \\
\text { nce }\end{array}$ & $\begin{array}{l}\text { VI } \\
\mathrm{F} \\
\end{array}$ \\
\hline 1(Constant) & 1.502 & $\begin{array}{l}1.52 \\
2\end{array}$ & & & $\begin{array}{l}.3 \\
26\end{array}$ & & \\
\hline Tangibel & .213 & .087 & 203 & $\begin{array}{l}2.4 \\
38\end{array}$ & & .335 & $\begin{array}{l}2.9 \\
88\end{array}$ \\
\hline Reliability & .516 & .106 & .522 & $\begin{array}{l}4.8 \\
81\end{array}$ & $\begin{array}{l}.0 \\
00\end{array}$ & .202 & $\begin{array}{l}4.9 \\
44\end{array}$ \\
\hline $\begin{array}{l}\text { Responsiv } \\
\text { eness }\end{array}$ & .204 & .089 & .211 & $\begin{array}{l}2.3 \\
02\end{array}$ & $\begin{array}{l}.0 \\
24 \\
\end{array}$ & .275 & $\begin{array}{l}3.6 \\
39 \\
\end{array}$ \\
\hline Empathy & 283 & .105 & 305 & $\begin{array}{l}2.6 \\
92\end{array}$ & $\begin{array}{l}.0 \\
09\end{array}$ & .180 & $\begin{array}{l}5.5 \\
43 \\
\end{array}$ \\
\hline Assu & .253 & .095 & .327 & $\begin{array}{l}2.6 \\
60\end{array}$ & $\begin{array}{l}.0 \\
09\end{array}$ & .153 & $\begin{array}{l}6.5 \\
44 \\
\end{array}$ \\
\hline
\end{tabular}

a. Dependent Variable: Kepuasan Pasien

Berdasarkan tabel di atas, bahwa semua variabel mempunyai nilai toleransi di atas 0,10 dan nilai VIF di bawah 10 . Sehingga dapat disimpulkan bahwa model regresi pada penelitian ini tidak terjadi multikolinieritas antar variabel bebas.

\section{Model Sub Struktural 2}

\section{Uji Normalitas dengan Grafik P-Plot}

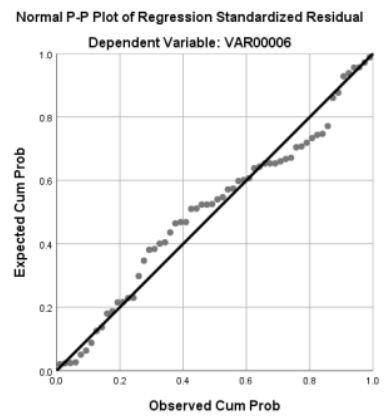

(Gambar 5.3. Grafik P-Plot)

Berdasarkan gambar di atas, diketahui bahwa data menyebar disekitar garis diagonal dan mengikuti arah garis diagonal atau grafik histogramnya menunjukkan pola distribusi normal, maka model regresi memenuhi asumsi normalitas.

\section{Uji Heteroskedastisitas}

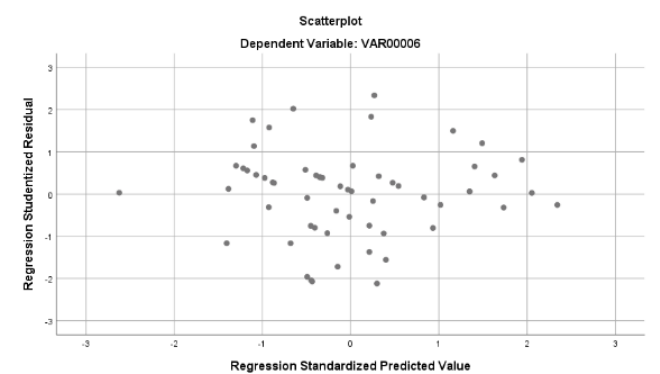

(Gambar 5.4. Hasil

\section{Analisis Heteroskedastisitas)}

Dari grafik scatterplot pada gambar $4.5 \mathrm{di}$ atas, terlihat bahwa tidak ada pola yang jelas, serta titik - titik menyebar secara acak di atas maupun di bawah angka 0 pada sumbu Y. Hal ini dapat disimpulkan bahwa tidak terjadi heteroskedasitas pada model regresi dalam penelitian ini.

Uji t

\section{Tabel 5.14 Uji t}

\section{Coefficients $^{\mathrm{a}}$}

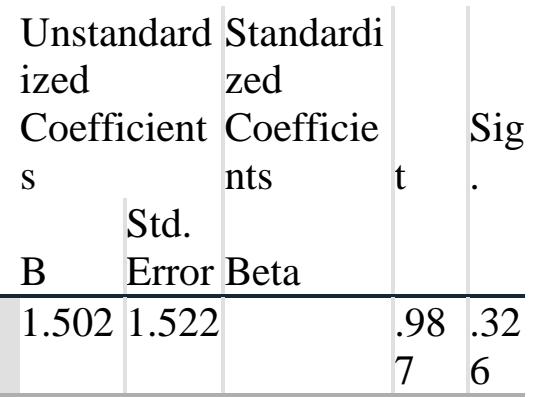




\begin{tabular}{|c|c|c|c|c|}
\hline Tangibel & .213 & .087 & 203 & $\begin{array}{ll}2.4 & .01 \\
38 & 7\end{array}$ \\
\hline Reliability & .516 & .106 & 522 & $\begin{array}{ll}4.8 & .00 \\
81 & 0\end{array}$ \\
\hline $\begin{array}{l}\text { Responsive } \\
\text { ness }\end{array}$ & .204 & .089 & 211 & $\begin{array}{ll}2.3 & .02 \\
02 & 4\end{array}$ \\
\hline Empathy & 283 & .105 & 305 & $\begin{array}{ll}2.6 & .00 \\
92 & 9\end{array}$ \\
\hline Assu & .253 & .095 & 327 & $\begin{array}{ll}2.6 & .00 \\
60 & 9 \\
\end{array}$ \\
\hline
\end{tabular}

a. Dependent Variable: Kepuasan Pasien

Berdasarkan tabel di atas, bahwa semua variabel mempunyai nilai toleransi di atas 0,10 dan nilai VIF di bawah 10 . Sehingga dapat disimpulkan bahwa model regresi pada penelitian ini tidak terjadi multikolinieritas antar variabel bebas.

\section{Tabel 5.15 Hasil Uji Simultan kepuasan pasien}

ANOVA $^{a}$

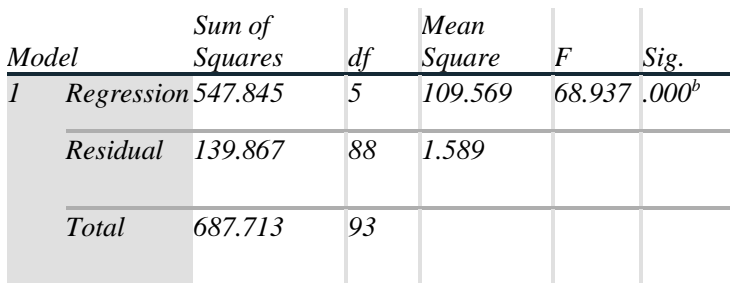

a. Dependent Variable: Kepuasan Pasien

b. Predictors: (Constant), Tangibel, Reliability, Responsiveness, Empathy, Assurance

Sumber: Data primer yang diolah, 2021

Untuk Uji F / uji simultan dalam penelitian ini menggunakan perbandingan nilai Signifikansi (Sig.) dengan 0,05

- Jika nilai hasil perhitungan Sig $<0,05$ signifikan

- Jika nilai hasil perhitungan Sig > 0,05 tidak signifikan

Dari output Anova diperoleh nilai Sig. sebesar 0,000 yang berarti dibawah 0,05 (alpha 5\%). Hal ini berarti variabel independent antara variabel tangible, reliability, responsiveness, empathy dan assurance secara bersama-sama berpengaruh signifikan terhadap kepuasan pasien. Dengan demikian dapat disimpulkan bahwa Hipotesis diterima..
Tabel 5.16 Koefisien Simultan (R2) Model Summary

Model Summary

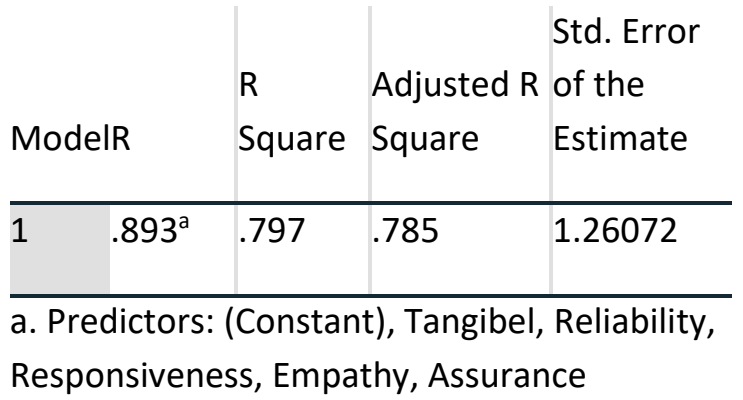

Sumber: Data primer yang diolah, 2021

Pada tabel 5.16 diperoleh nilai Adjusted R Square $=0,797=79,7 \%$. Ini berarti variabel bebas tangible, reliability, responsiveness, empathy dan assurance secara bersama-sama mempengaruhi variabel terikat kepuasan pasien sebesar $79,7 \%$ dan sisanya $20,3 \%$ dipengaruhi oleh variabel lain yang tidak masuk dalam penelitian ini.

Pembahasan

Berdasarkan hasil pengolahan data melalui SPSS maka pembahasan penelitian ini dapat disampaikan sbb :

1. Variabel Tangibles Berpengaruh Positif dan Signifikan Secara Parsial terhadap Kepuasan Pasien Pada RSUD Jaya Sumitra Kotabaru

Hasil penelitian ini menunjukkan bahwa variable Tangibles berpengaruh positif secara signifikan terhadap kepuasan pasien pada RSUD Jaya Sumitra Kotabaru.

Pernyataan tersebut dibuktikan berdasarkan hasil perhitungan menunjukkan bahwa tingkat t-hitung pada variabel tangibles sebesar $(2,438)>0,671$ pada taraf signifikansi 5\%. Menandakan bahwa t-hitung > t-tabel sehingga dapat disimpulkan bahwa $\mathrm{H} 0$ ditolak dan $\mathrm{Ha}$ diterima dengan arti bahwa tangibles berpengaruh secara signifikan terhadap kepuasan pasien.

Selanjutnya nilai koefisien regresi positif sebesar 0,203 artinya bahwa peningkatan terhadap nilai variable tangibel mampu meningkatkan kepuasan pasien pada 
RSUD Jaya Sumitra Kotabaru maksudnya bila saja variable tangibles dilakukan penambahan sebesar satu satuan maka akan meningkatkan nilai kepuasan pasien sebesar 0,203 dengan asumsi bahwa variable lainnya dianggap nol / tidak ada Hasil tanggapan responden diperoleh infiormasi bahwa indicator tertinggi berada pada pernyataan no 1 tentang, "Tersedianya ruang tunggu yang memadai" artinya bahwa semua pasien yang dijadikan responden dalam penelitian ini sangat setuju terhadap pernyataan yang dikemukakan sebesar $67 \%$. Dengan hasil rata-rata sebesar 4,4 dengan kategori sangat baik.

Menurut Tjiptono (2011), bukti fisik (tangible) merupakan meliputi fasilitas fisik, perlengkapan, pegawai, dan sarana komunikasi. Hal ini bisa berarti penampilan fisik, seperti gedung dan ruangan front office, tersedianya tempat parker, keberhasilan, kerapian dan kenyamanan ruangan, kelengkapan peralatan komunikasi dan penampilan petugasnya. Pandangan dari segi nilai dan harga itulah yang menjadi seperti apa kualitas barang/jasa tersebut.

Penelitian ini sejalan dengan temuan penelitian terdahulu yang dilakukan Dyah Nurfitri Maharani, Alwiyah Mukaddas, Indriani (2016) yang mengemukakan bahwa variable tangible berpengaruh Positif dan signifikan terhadap kepuasan pasien.

2. Variabel Reliability Berpengaruh Positif dan Signifikan Secara Parsial terhadap Kepuasan Pasien Pada RSUD Jaya Sumitra Kotabaru

Hasil penelitian ini menunjukkan bahwa variable reliability berpengaruh positif secara signifikan terhadap kepuasan pasien pada RSUD Jaya Sumitra Kotabaru.

$\begin{array}{lcr}\text { Pernyataan } & \text { tersebut dibuktikan } \\ \text { berdasarkan } & \text { hasil } & \text { perhitungan }\end{array}$ menunjukkan bahwa tingkat t-hitung pada variabel reliability sebesar $(4,881)>0,671$ pada taraf signifikansi 5\%. Menandakan bahwa t-hitung > t-tabel sehingga dapat disimpulkan bahwa $\mathrm{H} 0$ ditolak dan $\mathrm{Ha}$ diterima dengan arti bahwa reliability berpengaruh secara signifikan terhadap kepuasan pasien.

Selanjutnya nilai koefisien regresi positif sebesar 0,522 artinya bahwa peningkatan terhadap nilai variable reliability mampu meningkatkan kepuasan pasien pada RSUD Jaya Sumitra Kotabaru maksudnya bila saja variable reliability dilakukan penambahan sebesar satu satuan maka akan meningkatkan nilai kepuasan pasien sebesar 0,522 dengan asumsi bahwa variable lainnya dianggap nol / tidak ada Hasil tanggapan responden diperoleh infiormasi bahwa indicator tertinggi berada pada pernyataan no 2 tentang, "Kemampuan petugas memberikan perhatian dalam menyelesaikan kesulitan yang dilakukan oleh pelayanan" artinya bahwa semua pasien yang dijadikan responden dalam penelitian ini sangat setuju terhadap pernyataan yang dikemukakan sebesar 71,3\%. Dengan hasil rata-rata sebesar 4,9 dengan kategori sangat baik.

Menurut Parasuraman, dkk (1998) dalam Lupiyoadi dan Hamdani (2009) berpendapat kehandalan (Reliability) yaitu kemampuan perusahaan untuk memberikan pelayanan sesuai dengan apa yang dijanjikan secara akurat dan terpercaya. Kinerja harus sesuai dengan harapan pasien yang berarti ketepatan waktu, pelayanan yang sama untuk semua pasien tanpa kesalahan, sikap yang simpatik dan akurasi yang tinggi.

Penelitian ini sejalan dengan temuan penelitian terdahulu yang dilakukan Didik Santoso (2010) yang mengemukakan bahwa variable reliability berpengaruh Positif dan signifikan terhadap kepuasan pasien.

3. Variabel Responsiveness Berpengaruh Positif dan Signifikan Secara Parsial terhadap Kepuasan Pasien Pada RSUD Jaya Sumitra Kotabaru

Hasil penelitian ini menunjukkan bahwa variable responsiveness berpengaruh positif secara signifikan terhadap kepuasan pasien pada RSUD Jaya Sumitra Kotabaru. 
Pernyataan tersebut dibuktikan berdasarkan hasil perhitungan menunjukkan bahwa tingkat t-hitung pada variabel tangibel sebesar $(2,302)>0,671$ pada taraf signifikansi 5\%. Menandakan bahwa t-hitung > t-tabel sehingga dapat disimpulkan bahwa $\mathrm{H} 0$ ditolak dan $\mathrm{Ha}$ diterima dengan arti bahwa responsiveness berpengaruh secara signifikan terhadap kepuasan pasien.

Selanjutnya nilai koefisien regresi positif sebesar 0,211 artinya bahwa peningkatan terhadap nilai variable responsiveness mampu meningkatkan kepuasan pasien pada RSUD Jaya Sumitra Kotabaru maksudnya bila saja variable responsiveness dilakukan penambahan sebesar satu satuan maka akan meningkatkan nilai kepuasan pasien sebesar 0,211 dengan asumsi bahwa variable lainnya dianggap nol / tidak ada Hasil tanggapan responden diperoleh infiormasi bahwa indicator tertinggi berada pada pernyataan no 3 tentang, "Kemampuan petugas melayani masyarakat secara cepat" artinya bahwa semua pasien yang dijadikan responden dalam penelitian ini sangat setuju terhadap pernyataan yang dikemukakan sebesar $60 \%$. Dengan hasil rata-rata sebesar 4,1 dengan kategori sangat baik.

Ketanggapan (Responsiveness) merupakan kemampuan memberikan pelayanan yang dijanjikan dengan segera, akurat dan memuaskan (Tjiptono \& Candra, 2007). Hal ini berarti perusahaan memberikan jasanya secara tepat semenjak saat pertama. Dalam industri jasa, perusahaan memang bergantung pada kebutuhan pasien yang tidak konsisten dan cenderung abstrak. Oleh karena itu, tidak ada kesempatan bagi perusahaan jasa untuk memisahkan pelayanan yang benar dan yang salah.

Penelitian ini sejalan dengan temuan penelitian terdahulu yang dilakukan Delladari Mayefis, Auzal Halim, Rida Rahim (2015) yang mengemukakan bahwa variable responsiveness berpengaruh
Positif dan signifikan terhadap kepuasan pasien.

4. Variabel Assurance Berpengaruh Positif dan Signifikan Secara Parsial terhadap Kepuasan Pasien Pada RSUD Jaya Sumitra Kotabaru

Hasil penelitian ini menunjukkan bahwa variable assurance berpengaruh positif secara signifikan terhadap kepuasan pasien pada RSUD Jaya Sumitra Kotabaru.

Pernyataan tersebut dibuktikan berdasarkan hasil perhitungan menunjukkan bahwa tingkat t-hitung pada variabel assurance sebesar $(2,660)>0,671$ pada taraf signifikansi 5\%. Menandakan bahwa t-hitung > t-tabel sehingga dapat disimpulkan bahwa $\mathrm{H} 0$ ditolak dan $\mathrm{Ha}$ diterima dengan arti bahwa assurance berpengaruh secara signifikan terhadap kepuasan pasien.

Selanjutnya nilai koefisien regresi positif sebesar 0,327 artinya bahwa peningkatan terhadap nilai variable assurance mampu meningkatkan kepuasan pasien pada RSUD Jaya Sumitra Kotabaru maksudnya bila saja variable assurance dilakukan penambahan sebesar satu satuan maka akan meningkatkan nilai kepuasan pasien sebesar 0,327 dengan asumsi bahwa variable lainnya dianggap nol / tidak ada Hasil tanggapan responden diperoleh infiormasi bahwa indicator tertinggi berada pada pernyataan no 5 tentang, "Keramahatamahan dan kesopanan petugas dalam melayani masyarakat kepada pasien" artinya bahwa semua pasien yang dijadikan responden dalam penelitian ini sangat setuju terhadap pernyataan yang dikemukakan sebesar $60,6 \%$. Dengan hasil rata-rata sebesar 3,9 dengan kategori sangat baik.

Menurut Parasuraman, dkk (1998) dalam jurnal Renata dan Suryono (2013) jaminan dan kepastian (assurance) yaitu meliputi kemampuan petugas atas pengetahuannya terhadap produk secara tepat, keramah tamahan, perhatiaan dan kesopanan, ketrampilan dalam memberikan informasi, kemampuan dalam memberikan keamanan dalam memanfaatkan jasa yang ditawarkan 
dan kemampuan dalam menanamkan kepercayaan pasien terhadap perusahaan, sifat dapat dipercaya yang dimiliki para staf, bebas dari bahaya, resiko atau pun keraguan

Penelitian ini sejalan dengan temuan penelitian terdahulu yang dilakukan Abdul Razak (2016) dan Dianita Rifqia Putri (2017) yang mengemukakan bahwa variable assurance berpengaruh Positif dan signifikan terhadap kepuasan pasien.

5. Variabel Empathy Berpengaruh Positif dan Signifikan Secara Parsial terhadap Kepuasan Pasien Pada RSUD Jaya Sumitra Kotabaru

Hasil penelitian ini menunjukkan bahwa variable empathy berpengaruh positif secara signifikan terhadap kepuasan pasien pada RSUD Jaya Sumitra Kotabaru.

Pernyataan tersebut dibuktikan berdasarkan hasil perhitungan menunjukkan bahwa tingkat t-hitung pada variabel empathy sebesar $(2,692)>0,671$ pada taraf signifikansi 5\%. Menandakan bahwa t-hitung > t-tabel sehingga dapat disimpulkan bahwa $\mathrm{H} 0$ ditolak dan $\mathrm{Ha}$ diterima dengan arti bahwa empathy berpengaruh secara signifikan terhadap kepuasan pasien.

Selanjutnya nilai koefisien regresi positif sebesar 0,305 artinya bahwa peningkatan terhadap nilai variable empathy mampu meningkatkan kepuasan pasien pada RSUD Jaya Sumitra Kotabaru maksudnya bila saja variable empathy dilakukan penambahan sebesar satu satuan maka akan meningkatkan nilai kepuasan pasien sebesar -0,305 dengan asumsi bahwa variable lainnya dianggap nol / tidak ada Hasil tanggapan responden diperoleh infiormasi bahwa indicator tertinggi berada pada pernyataan no 4 tentang, "Memberikan Perhatian khusus kepada masyarakat yang berurusan" artinya bahwa semua pasien yang dijadikan responden dalam penelitian ini sangat setuju terhadap pernyataan yang dikemukakan sebesar $62,8 \%$. Dengan hasil rata-rata sebesar 4,3 dengan kategori sangat baik.
Menurut Parasuraman, dkk (1998) dalam Lupiyoadi dan Hamdani (2009), empati (Empathy) yaitu perhatiaan dengan memberikan sikap yang tulus bersifat individual atau pribadi yang diberikan perusahaan kepada pasien seperti kemudahan untuk menghubungi perusahaan, kemampuan petugas untuk berkomunikasi dengan pasien dan usaha perusahaan untuk memahami keinginan dan kebutuhan pasien.

Penelitian ini sejalan dengan temuan penelitian terdahulu yang dilakukan Atika Dalili Akhmad, Dirga, Sudewi Mukaromah, Nur Adliani, Sukrasno (2019) yang mengemukakan bahwa variable empathy berpengaruh Positif dan signifikan terhadap kepuasan pasien.

\section{KESIMPULAN}

1. Berdasarkan hasil perhitungan dan pembahasan yang telah dilakukan pada bab terdahulu, maka kesimpulan dalam penelitian ini dapat disimpulkan sebagai berikut:

2. Variable Bukti Fisik (Tangibles), Reliabilitas (Reliability),

Ketanggapan (Responsiveness), Jaminan (Assurance), dan Empati (Empathy) berpengaruh secara simultan terhadap Kepuasan Pasien pada RSUD Kotabaru Kalimantan Selatan

3. Variable Bukti Fisik (Tangibles), Reliabilitas (Reliability),

Ketanggapan (Responsiveness), Jaminan (Assurance), dan Empati (Empathy) berpengaruh positif secara signifikan terhadap Kepuasan Pasien pada RSUD Kotabaru Kalimantan Selatan

4. Variable yang Dominan berpengaruh Reliabilitas (Reliability), terhadap Kepuasan Pasien pada RSUD Kotabaru Kalimantan Selatan 


\section{Daftar Pustaka}

Aritonang. 2005. Membangun Kepuasan Pasien Melalui Kualitas Pelayanan, Usahawan Mei, Yogyakarta.

Budiman (1996). Analisis Hubungan Tingkat Kepuasan Pasien Rawat Jalan Terhadap Pelayanan Instalasi Farmasi Dengan Minat Pasien Menebus Kembali Resep Obat di Instalasi Farmasi RSUD Budhi Asih Tahun 1996, Tesis ,UI, Jakarta.

Eko Prasojo (2009). Persepsi masyarakat terhadap kinerja, keterlibatan dan partisipasi dalam pelayanan pendidikan kesehatan dan kependudukan, PT. Adnan, Semarang.

Fandy Tjiptono. 1996. Konsep Kepuasan Pasien. Prenhallindo, Jakarta

Feigenbaum (1991). Analisis Pengaruh Kualitas Layanan Terhadap Kepuasan Pasien Pada Rumah Sakit. CV. Tarsito, Bandung

Gary (2016). Analisis PengelolaanObat Di Instalasi Farmasi RSUP H. Adam Malik Medan Tahun 2016. Skripsi Fakultas Farmasi USU, Medan.

Kolter, 1994. Antara Kinerja dan Harapan. Kadir Malewa, Bandung

Parmudji. 1994. Manajemen Sumber Daya Manusia. Kencana, Jakarta

Poerwadarmita (1995). Teori dan Penerapan, Penerbit Buku Kedokteran, EGC, Jakarta.

Pohan 2007. Prinsip-prinsip Total Quality Service, Penerbit Andi Yogyakarta

Ratminto . (2006) . Manajemen Kinerja Rumah Sakit. Rajawali Pers . Jakarta

Saefullah, (1999), Perilaku Organisasi. Edisi Sepuluh, PT. Andi: Yogyakarta 